\title{
PENGATURAN PENGALIHAN PIUTANG DARI KLIEN KEPADA PERUSAHAAN FACTOR DALAM KEGIATAN ANJAK PIUTANG
}

\author{
Oleh: \\ Anak Agung Putu Krisna Putra ${ }^{1}$, I Made Udiana²
}

\begin{abstract}
Abstrack
The Presidential Regulation Number 9 of 2009 on Financing Agency described the sense of factoring is financing activities in the form of purchases of short-term trade receivables of a company following the maintenance on these receivables. Factoring activity can be used as an alternative for businesses to help finance company which can facilitate the flow of funds so that the company run can run well so as to compete to improve the quality and quantity of the products to be supplied. The parties involved in the transaction of business activities factoring namely client, customer and company factors. Clients are companies that sell short-term accounts receivable financing company. Customer is the parties receivables owed to the seller (client). While the Company Factor, which are companies that do business financing in the form of purchase and I or transfer and maintenance of accounts or short- term bills of a company from trading operations within or outside the country. In the factoring activity when clients transfer or sell their receivables to the factor company must observe the considerations used. The sales transaction to the company's accounts receivable factor by the client without the knowledge of the customer will have an impact on the law of each parties. Responsibility for the factoring agreement is when the customer is unable to meet its obligations to the company factor.
\end{abstract}

Keywords : factoring, financing, transfer of receivables.

\begin{abstract}
Abstrak
Peraturan Presiden Nomor 9 Tahun 2009 tentang Lembaga Pembiayaan menjelaskan pengertian dari anjak piutang yaitu kegiatan pembiayaan dalam bentuk pembelian piutang dagang jangka pendek suatu perusahaan berikut pengurusan atas piutang tersebut. Kegiatan anjak piutang ini dapat dijadikan alternatif bagi pelaku bisnis untuk membantu pembiayaan perusahaan untuk memperlancar aliran pendanaan sehingga perusahaan dapat berjalan dengan baik mampu bersaing untuk meningkatkan kualitas maupun kuantitas produk yang akan diberikan. Pihak-pihak yang terlibat dalam transaksi kegiatan usaha anjak piutang yaitu Klien, customer dan perusahaan factor. Klien merupakan perusahaan yang menjual piutang dagang jangka pendek kepada perusahaan pembiayaan. Customer adalah pihak yang berhutang kepada penjual piutang (klien). Sedangkan Perusahaan Factor, yaitu perusahaan yang melakukan usaha pembiayaan dalam bentuk pembelian dan/atau pengalihan serta pengurusan

1 Mahasiswa Magister Ilmu Hukum Universitas Udayana, Denpasar, Bali. Jl. Kapten Japa Gg. XVIII No. 4 Denpasar. Email : kris_dugonk@yahoo.com

2 Dosen Magister Ilmu Hukum Universitas Udayana, Denpasar, Bali. Jl. Wr Supratman Gg. Swadaya X No. 10 Denpasar, Email : Udianabali@gmail.com
\end{abstract}


piutang atau tagihan jangka pendek suatu perusahaan dari transaksi perdagangan dalam atau luar negeri. Dalam kegiatan anjak piutang ketika klien mengalihkan atau menjual piutangnya kepada perusahaan factor harus tetap memperhatikan pertimbangan-pertimbangan yang digunakan. Transaksi penjualan piutang kepada perusahaan factor oleh klien tanpa sepengetahuan customer akan berdampak hukum pada masing-masing pihak. Tanggung jawab dalam perjanjian anjak piutang ini adalah ketika pihak customer yang tidak mampu memenuhi kewajibannya kepada perusahaan factor.

Kata Kunci : anjak piutang, pembiayaan, pengalihan piutang.

\section{PENDAHULUAN}

\subsection{Latar Belakang}

Dunia bisnis tetap bersaing secara sehat antara perusahaan yang satu dengan perusahaan lainnya. Semakin besar persaingan tersebut membuat setiap perusahaan memberikan pelayanan terbaik kepada para pelanggannya. Perkembangan dibidang ekonomi tersebut demikian atraktif, dinamis, sangat prospektif dan penuh persaingan. ${ }^{3}$ Kegiatan yang terjadi dalam dunia bisnis dapat menimbulkan permasalahan hukum yang akan dihadapi oleh berbagai perusahaan. Bantuan dana dapat diperoleh melalui pinjaman dari lembaga pembiayaan sehingga suatu perusahaan dapat berjalan dengan lancar meningkatkan produktifitas agar mampu bersaing dalam dunia bisnis.

Lembaga pembiayaan sudah diatur dalam Peraturan Presiden Nomor 9 Tahun 2009 tentang Lembaga Pembiayaan dan Peraturan Menteri Keuangan Nomor 84/PMK.012/2006 tentang Perusahaan Pembiayaan. Lembaga pembiayaan merupakan

Syarin Naihasy, 2007, Hukum Bisnis (Business Law), Mida Pustaka, Yogyakarta, hlm. 7 badan usaha yang melakukan kegiatan pembiayaan, dengan tidak menarik dana secara langsung dari masyarakat. Lembaga pembiayaan disini antara lain meliputi perusahaan pembiayaan merupakan badan usaha khusus didirikan untuk melakukan kegiatan usaha diantaranya yaitu anjak piutang. Peraturan Presiden Republik Indonesia Nomor 9 Tahun 2009, menjelaskan pengertian anjak piutang adalah kegiatan pembiayaan dalam bentuk pembelian piutang dagang jangka pendek suatu perusahaan, berikut pengurusan atas piutang tersebut. Perusahaan yang melakukan anjak piutang disebut penganjak piutang (factor) yaitu pihak yang mempunyai kegiatan membeli piutang dari pihak lain. ${ }^{4}$ Kegiatan usaha ini bisa dijadikan alternatif bagi pelaku bisnis untuk membantu pembiayaan perusahaan untuk memperlancar aliran pendanaan sehingga perusahaan yang dijalankan dapat berjalan dengan baik sehingga mampu bersaing untuk meningkatkan kualitas maupun kuantitas produk yang akan diberikan.

Rinus Pantouw, 2006, Hak Tagih Factor Atas Piutang Dagang, Kencana Prenanda Media Group, Jakarta, hlm. 8. 
Pihak yang terlibat dalam transaksi anjak piutang, sebagai berikut:

1. Klien, yaitu pihak yang mempunyai piutang, yang akan dijual atau dialihkan kepada perusahaan factor.

2. Customer, yaitu pihak yang berhutang kepada penjual piutang (klien).

3. Perusahaan Factor, yaitu perusahaan yang memberikan jasa anjak piutang, dalam hal ini perusahaan factor bertindak sebagai pihak pembeli piutang. Transaksi anjak piutang mencakup pengalihan piutang oleh klien sebagai pemilik piutang kepada perusahaan factor. Mengingat piutang klien dialihkan kepada perusahaan factor, maka selanjutnya perusahaan factor yang mempunyai hak untuk menagih piutang itu kepada customer. Dalam anjak piutang ketika klien mengalihkan atau menjual piutangnya kepada perusahaan factor, harus tetap memperhatikan pertimbanganpertimbangan yang digunakan. Transaksi penjualan piutang kepada perusahaan factor oleh klien yang tanpa sepengetahuan customer akan berdampak hukum pada masingmasing pihak. Tanggung jawab dalam perjanjian anjak piutang ini adalah ketika pihak customer yang tidak mampu memenuhi kewajibannya kepada perusahaan factor.

\subsection{Perumusan Masalah}

1. Bagaimanakah pengaturan
pengalihanataupenjualanpiutang dari klien kepada perusahaan factor tanpa sepengetahuan customer?

2. Bagaimanakah tanggung jawab klien apabila customer tidak dapat memenuhi kewajibannya kepada perusahaan factor?

\subsection{Tujuan Penelitian}

Tujuan yang ingin dicapai, yaitu:

1. Untuk mengetahui dan memahami pengaturan pengalihan piutang dari klien kepada perusahaan factor tanpa sepengetahuan customer.

2. Untuk mengetahui dan memahami tanggung jawab klien apabila customer tidak dapat memenuhi kewajibannya kepada perusahaan factor.

\section{METODE PENELITIAN}

Dalam penelitian ini digunakan metode penelitian hukum normatif yang merupakan penelitian mengenai substansi hukum yang terdiri dari norma, peraturanperundang-undangan, asas-asas hukum dan doktrin. ${ }^{5}$

Penelitian menggunakan pendeka-tan perundang-undangan (the statute approach) serta analisis konsep hukum (analitical and conceptual approach). Pendekatan perundangundangan merupa-kan pendekatan yang dilakukan dengan menelaah peraturan perundang-undangan yang

5 Mukti Fajar dan Yulianto Achmad, 2010, Dualisme Penelitian Hukum Normatif dan Empiris, PT Pustaka Pelajar, Yogyakarta, hlm. 28. 
berhubungan dengan perusahaan pembiayaan anjak piutang. Pendekatan analisis konsep hukum dilakukan dengan menggunakan konsep dan prinsip-prinsip hukum serta menelusuri arti dari istilah hukum yang terdapat dalam perundang-undangan.

Sumber bahan hukum dalam penelitian ini terdiri dari bahan hukum primer yaitu bahan hukum yang mempunyai kekuatan hukum mengikat, antara lain UUD 1945, Kitab Undang-Undang Hukum Perdata, Peraturan Presiden RI No. 9 Tahun 2009 tentang Lembaga Pembiayaan dan Peraturan Menteri Keuangan No. 84/PMK.012/2006 tentang Perusahaan Pembiayaan. Bahan hukum sekunder yang digunakan terdiri dari literaturliteratur, buku ilmu hukum, jurnal hukum, dan artikel hukum. Bahan hukum tersier digunakan untuk melengkapi bahan hukum primer dan sekunder, berupa kamus Bahasa Indonesia.

Dalam pengumpulan bahan hukum dilakukan menggunakan teknik studi kepustakaan yaitu melakukan penelusuran mengenai bahan-bahan hukum terkait dengan permasalahan yang hendak diteliti. ${ }^{6}$ Penelusuran tersebut dilakukan dengan membaca ataupun melihat melalui media internet yang kemudian dicatat, diidentifikasi dan di klasifikasikan berdasarkan materi yang hendak diteliti. ${ }^{7}$

\footnotetext{
Bambang Sunggono, 2007, Metodelogi Penelitian Hukum, RajaGrafindo Persada, Jakarta, hlm. 115.

7 Mukti Fajar dan Yulianto Achmad, Op.cit, hlm. 160 .
}

Teknik analisis bahan hukum menggunakan teknik deskripsi yaitu dengan memberikan gambaran, dengan sistematis menyeluruh terhadap suatu permasalahan dan dianalisis kemudian menarik suatu kesimpulan berdasarkan permasalahan penelitian.

\section{HASIL DAN PEMBAHASAN \\ 3.1. Pengaturan Pengalihan Piutang Dari Klien Kepada Perusahaan Factor Tanpa Sepengetahuan Customer}

Perusahaan pembiayaan anjak piutang ini dapat mengatasi kendala yang dialami oleh suatu perusahaan. Kehadiran perusahaan pembiayaan anjak piutang ini bisa membantu mengatasi permasalahan dalam mengelola kredit, sehingga klien bisa berkosentrasi untuk meningkatkan produk maupun penjualannya. Akan tetapi tidak semua piutang dapat dijual kepada perusahaan factor karena perusahaan factor telah memiliki patokan atau pedoman tersendiri secara khusus.

Pasal 1338 KUHPerdata menentukan bahwa setiap perjanjian yang dibuat secara sah sebagai undangundang, bagi para pihak yang membuat perjanjian. Suatu perjanjian merupakan peristiwa dimana seseorang berjanji kepada orang lain untuk melaksanakan dan melakukan sesuatu hal. ${ }^{8}$ Perjanjian itu kemudian menimbulkan hubungan hukum antara klien dan customer. Hubungan hukum

Subekti, 2001, Pokok-Pokok Hukum Perdata, PT. Intermasa, Jakarta, hlm. 36. 
tersebut kemudian timbul hak dan kewajiban. Kewajiban merupakan keha-rusan untuk melakukan sesuatu perbuatan tertentu. ${ }^{9}$

Dalam pengalihan piutang, debitur (customer) memang tidak memiliki peran yang aktif akan tetapi dalam ketentuan pengalihan piutang telah dijelaskan secara jelas mengacu pada Pasal 613 KUHPerdata. Dengan melihat Pasal 613 KUHPerdata tersebut, maka pengalihan piutang haruslah dilakukan dengan membuat akta otentik, dan tidak akan berakibat bagi si berutang jika belum ada pemberitahuan atau secara tertulis disetujui serta diakui. Begitupun dengan pengalihan piutang yang ada pada kegiatan anjak piutang ini, pengalihan tersebut harus dilaksanakan sesuai dengan aturan yang terdapat dalam KUHPerdata.

Berkaitan dengan ketentuan perundang-undangannya apabila pengalihan piutang dari klien kepada perusahaanfactor tanpa sepengetahuan customer, memang tidak terdapat ketentuan pengaturan khusus yang mengatur mengenai pengalihan piutang dalam perjanjian anjak piutang. Namun terdapat ketentuan perundangundangan yang dapat dijadikan dasar ketentuan hukum mengenai jual beli dan pengalihan piutang tersebut yaitu dalam Pasal 613 KUHPerdata.

Dalam kegiatan anjak piutang terdapat dua jenis pemberitahuan

Bachsan Mustafa, 2003, Sistem Hukum Indonesia Terpadu, PT. Citra Aditya Bakti, Bandung, hlm. 41. pengalihan piutang yaitu Disclosed Factoring dan Undisclosed Factoring. ${ }^{10} \quad$ Disclosed factoring merupakan pengalihan piutang oleh klien kepada perusahaan factor dengan persetujuan dan diketahui pihak customer. ${ }^{11}$ Sedangkan undisclosed factoring adalah pengalihan piutang oleh klien kepada perusahaan factor tanpa memberitahukan pihak customer. ${ }^{12}$ Dalam jenis pengalihan piutang undisclosed factoring ini pada hakikatnya tidak sesuai dengan aturan yang terdapat dalam Pasal 613 KUHPerdata. Seperti yang diatur dalam Pasal 613 KUHPerdata yakni pengalihan piutang baru mengikat debitur (customer) apabila pengalihan piutang tersebut diberitahukan kepada debitur (customer) disetujui dan diakui olehnya secara tertulis. Mengenai pengalihan piutang dalam anjak piutang haruslah diberitahukan kepada customer karena jika

terjadi sesuatu hal yang tidak diinginkan dilakukan oleh customer, akan menimbulkan akibat hukum kepada customer.

\subsection{Tanggung Jawab Klien Apabila Customer Tidak Dapat Memenuhi Kewajibannya Kepada Perusa-haan Factor}

Pengertiantanggungjawabsecara garis besar yaitu adanya kesadaran dari seseorang terhadap perbuatannya

\footnotetext{
10 Sunaryo, 2009, Hukum Lembaga Pembiayaan, Sinar Grafika, Jakarta, hlm. 82.

11 Miranda Nasihin, 2012, Segala Hal Tentang Hukum Lembaga Pembiayaan, Buku Pintar, Yogyakarta., hlm. 61

$12 \quad$ Ibid, hlm. 60
} 
baik itu secara kesengajaan ataupun tidak. Tanggung jawab secara sempit yaitu kepercayaan seseorang yang diamanatkan kepada orang lain yang harus dilakukan. Tanggung jawab juga diartikan sebagai usaha dari seseorang untuk melakukan amanat secara cermat dan teliti. ${ }^{13}$

Tanggung jawab hukum adalah keterikatan, artinya tanggung jawab itu karena adanya hubungan hukum diantara para pihak. Hubungan hukum ini adalah hubungan antara hak dan kewajiban pihak yang satu dengan lainnya. ${ }^{14}$ Apabila dikaji lebih dalam, tanggung jawab merupakan beban yang wajib dipenuhi sebagai akibat dari perbuatan yang dilakukan. Dalam hal ini klien sebagai pihak yang menerima jasa dari anjak piutang menjual barang secara kredit jangka pendek kepada customer, sedangkan customer mempunyai kewajiban untuk membayar utang jangka pendek tersebut.

Disini kewajiban bagi klien karena telah menerima dan memanfaatkan jasa anjak piutang tersebut adalah membayar biaya anjak piutang, yang terdiri dari biaya penggunaan jasa untuk mengelola pembukuan penjualan dari transaksi penjualan, serta biaya karena klien memperoleh pembiayaan dana tunai

M.Yatimin Abdullah, 2006, Pengantar Studi Etika, PT. Raja Grafindo Persada, Jakarta, hlm. 271.

14 R. Soeroso, 2011, Pengantar Ilmu Hukum, Sinar Grafika, Jakarta, hlm. 269 dari lembaga anjak piutang. ${ }^{15}$ Apabila customer tidak mengakui kebenaran piutang dan jumlah piutang yang dimiliki oleh klien, atau customer mengalami kebangkrutan sehingga tidak dapat melunasi tagihan, maka pihak klien harus membayar kepada perusahaan factor nilai piutang yang dijualnya tersebut. ${ }^{16}$

Dalamhalmengetahuibagaimana tanggung jawab klien apabila customer tidak dapat memenuhi kewajibannya kepada perusahaan factor adalah tergantung dari jenis perjanjian yang disepakati oleh para pihak (klien dan perusahaan factor). Terdapat dua jenis perjanjian anjak piutang yaitu with recourse dan without recourse. With recourse adalah perjanjian apabila perusahaan factor tidak mendapatkan tagihannya dari customer, maka klien selaku penjual piutang tetap bertanggung jawab untuk melunasi tagihan tersebut. ${ }^{17}$ Sedangkan Without Recourse merupakan perjanjian apabila terjadi kegagalan dalam hal penagihan piutang kepada customer, itu merupakan tanggung jawab dari pihak perusahaan factor sendiri. ${ }^{18}$

Apabila dalam perjanjian tersebut segala sesuatunya telah diatur dan disepakati, termasuk kesepakatan tentang jenis anjak piutang yang

Khotibul Umam, 2010, Hukum Lembaga Pembiayaan : Hak dan Kewajiban Nasabah Pengguna Jasa Lembaga Pembiayaan, Pustaka Yustisia, Yogyakarta, hlm. 31.

Sunaryo, Op.cit, hlm. 91.

Miranda Nasihin, Op.cit, hlm. 63.

Ibid, hlm. 64 . 
dipilih dengan konsekwensi siapa yang memikul risiko dalam hal gagalnya penagihan piutang dagang atau pihak customer tidak dapat memenuhi kewajibannya, maka perjanjian yang disepakati itu mengikat para pihak seperti halnya undang-undang. Perjanjian anjak piutang memang tidak secara tegas dan khusus diatur dalam KUHPerdata, namun dalam Pasal 1320 KUHPerdata dijelasakan tentang syarat sahnya suatu perjanjian. Pasal 1338 ayat (1) KUHPerdata juga menjelaskan semua perjanjian yang dibuat secara sah berlaku sebagai undang-undang bagi mereka yang membuatnya.

Jenis perjanjian anjak piutang yang dijelaskan diatas sudah menjadi konsekwensi hukum dari mengikatnya suatu perjanjian anjak piutang bagi para pihak apabila sudah dibuat secara sah menurut hukum dengan dasar ketentuan Pasal 1320 dan Pasal 1338 KUHPerdata. Berdasarkan pemaparan diatas dalam hal perjanjian anjak piutang tersebut, maka tanggung jawab pihak klien sudah jelas didasarkan pada perjanjian (perikatan) yang telah disepakatinya oleh perusahaan factor. Apabila yang disepakati jenis perjanjian anjak piutang dengan with recourse maka pihak klien yang bertanggung jawab apabila tidak terbayarnya piutang oleh customer kepada perusahaan factor. Sebaliknya apabila yang disepakati jenis perjanjian anjak piutang dengan without recourse maka perusahaan factor yang menerima risiko tidak terbayarnya piutang oleh customer.

\section{PENUTUP \\ 4.1. Simpulan}

1. Pengalihan piutang dari klien kepada perusahaan factor tanpa sepengetahuan customer dalam peraturan perundangundangan tidak diatur secara khusus ketentuan yang mengatur tentang pengalihan piutang dalam perjanjian anjak piutang. Akan tetapi dalam KUHPerdata terdapat ketentuan pengalihan piutang dalam Pasal 613 yaitu pengalihanpiutangbarumengikat debitur apabila pengalihan piutang tersebut diberitahukan kepada debitur disetujui dan diakui olehnya secara tertulis. Jadi customer hanya dapat terikat untuk memenuhi kewajibannya apabila dirinya telah mengetahui dan menyetujui adanya pengalihan piutang dari klien kepada perusahaan factor. Namun apabila customer tidak mengetahui adanya pengalihan piutang dari klien kepada perusahaan factor, maka customer tidak berkewajiban untuk memenuhi tagihan secara langsung kepada perusahaan factor selaku klien baru.

2. Tanggung jawab klien apabila customer tidak memenuhi kewajibannyakepadaperusahaan factor yaitu tergantung dari 
jenis perjanjian anjak piutang yang telah disepakati. Apabila jenis perjanjian anjak piutang yang disepakati adalah with recourse maka disini klien selaku penjual piutang tetap bertanggung jawab untuk melunasi utang customer kepada perusahaan factor apabila terjadi kegagalan dalam hal penagihan piutang. Sebaliknya, apabila jenis perjanjian anjak piutang yang disepakati adalah without recourse maka perusahaan factor yang menanggung seluruh risiko tidak tertagihnya piutang.

\subsection{Saran}

1. Sebaiknya dalam proses pengalihan piutang dalam kegiatan anjak piutang wajib diberitahukan kepada customer, disetujui dan diakui oleh customer secara tertulis, sehingga pengalihan piutang dari klien kepada perusahaan factor itu mengikat pihak customer.

2. Dengan belum adanya ketentuan yang mengatur tentang pengalihan piutang dalam kegiatan anjak piutang, maka perlu kiranya dibuatkan suatu ketentuan khusus yang secara rinci mengatur tentang pengalihan piutang tersebut. Hal ini cukup penting mengingat perlu adanya suatu kepastian hukum terutama mengenai pengalihan piutang serta untuk memberikan perlindungan hukum bagi para pihak yaitu klien, customer dan perusahaan factor.

\section{DAFTAR PUSTAKA}

\section{Buku}

Bachsan Mustafa, 2003, Sistem Hukum Indonesia Terpadu, PT. Citra Aditya Bakti, Bandung.

Bambang Sunggono, 2007, Metodelogi

Penelitian Hukum, RajaGrafindo

Persada, Jakarta.

Khotibul Umam, 2010, Hukum

Lembaga Pembiayaan : Hak dan

Kewajiban Nasabah Pengguna

Jasa Lembaga Pembiayaan,

Pustaka Yustisia, Yogyakarta.

Miranda Nasihin, 2012, Segala Hal

Tentang Hukum Lembaga

Pembiayaan, Buku Pintar,

Yogyakarta.

Mukti Fajar dan Yulianto Achmad, 2010, Dualisme Penelitian Hukum Normatif dan Empiris,

PT Pustaka Pelajar, Yogyakarta.

M.Yatimin Abdullah, 2006, Pengantar

Studi Etika, PT. Raja Grafindo

Persada, Jakarta.

Rinus Pantouw, 2006, Hak Tagih

Factor Atas Piutang Dagang,

Kencana Prenanda Media Group, Jakarta

Subekti, 2001, Pokok-Pokok Hukum Perdata, PT. Intermasa, Jakarta.

Sunaryo, 2009, Hukum Lembaga

Pembiayaan, Sinar Grafika, Jakarta. 
Soeroso, 2011, Pengantar Ilmu

Hukum, Sinar Grafika, Jakarta.

Syarin Naihasy, 2007, Hukum Bisnis

(Business Law), Mida Pustaka, Yogyakarta.

\section{Peraturan Perundang Undangan :}

Kitab Undang-Undang Hukum Perdata.

Peraturan Presiden Repulik Indonesia

No. 9 Tahun 2009 tentang Lembaga Pembiayaan.

Peraturan Menteri Keuangan No. 84/PMK.012/2006 tentang

Perusahaan Pembiayaan. 